\title{
Deiksis Persona dan Pesan Persuasif dalam Buku Pengembangan Diri: Ingatkan Aku Karya Fitria NA
}

\author{
Putri Nahdiah' ${ }^{1)}$ \\ Universitas Indraprasta PGRI \\ Jalan Nangka No. 58 C/TB. Simatupang, Tanjung Barat, Jakarta Selatan 12530 \\ Bambang Sumadyo ${ }^{2)}$ \\ Universitas Indraprasta PGRI \\ Jalan Nangka No. 58 C/TB. Simatupang, Tanjung Barat, Jakarta Selatan 12530 \\ Sumaryati Tjitro Sumarto ${ }^{3)}$ \\ Universitas Indraprasta PGRI \\ Jalan Nangka No. 58 C/TB. Simatupang, Tanjung Barat, Jakarta Selatan 12530 \\ putrinahdiah@gmail.com ${ }^{1)}$
}

\begin{abstract}
This research was conducted to analyze personal deixis and persuasive messages in the self improvement book: Ingatkan Aku by Fitria NA. The focus of the research were 1) to reveal the form of personal deixis; 2) knowing persuasive messages; and 3) describes the relationship between personal deixis forms and persuasive messages in the self-improvement book: Ingatkan Aku by Fitria NA. The research was conducted by using the analysis method by observing notes and paying attention to expert theories related to persona deixis and persuasive messages. The results found 67 data of personal deixis and persuasive messages that were concluded: 1) The form of person deixis is dominated by a singular second person pronoun. This suggests that Fitria NA's self-improvement book: Ingatkan Aku shows a two-way communication in writing between the writer and the reader. The goal is to attract attention and invite readers to understand, understand, and carry out the good suggestions that the author conveyed in the self-improvement book. 2) Persuasive messages with religious themes. 3) The relationship between personal deixis and persuasive messages is the emergence of an affirming impression. The dominance of the personal deixis that appears shows that the message is conveyed personally. It turns out that this is used so that the message is better understood, explored, and implemented by the reader.
\end{abstract}

Keywords: Deixis Persona, Persuasive Message, Self Development Book, Remind Me, Fitria NA

\begin{abstract}
Abstrak
Penelitian ini dilakukan untuk menganalisis deiksis persona dan pesan persuasif pada buku pengembangan diri: Ingatkan Aku karya Fitria NA. Fokus penelitian yakni 1) mengungkapkan bentuk deiksis persona; 2) mengetahui pesan persuasif; dan 3) memaparkan hubungan bentuk deiksis persona dan pesan persuasif dalam buku pengembangan diri: Ingatkan Aku karya Fitria NA. Penelitian dilakukan dengan metode analisis simak catat dan memperhatikan teori-teori ahli yang berkaitan dengan deiksis persona dan pesan persuasif. Hasilnya ditemukan 67 data deiksis persona dan pesan persuasif yang disimpulkan: 1) Bentuk deiksis persona didominasi oleh kata ganti orang kedua tunggal. Hal ini menunjukkan bahwa buku pengembangan diri: Ingatkan Aku karya Fitria NA menunjukkan komunikasi dua arah dalam tulisan antara penulis dan pembaca. Tujuannya, untuk menarik perhatian dan mengajak pembaca memahami, mengerti, dan melaksanakan anjuran-anjuran baik yang disampaikan penulis dalam buku pengembangan diri. 2) Pesan-pesan persuasif bertemakan keagamaan. 3) Hubungan bentuk deiksis persona dan pesan
\end{abstract}


persuasif adalah munculnya kesan menguatkan. Dominasi deiksis persona yang muncul memperlihatkan bahwa pesan disampaikan secara personal. Ternyata hal tersebut digunakan agar pesan lebih dipahami, didalami, dan dilaksanakan pembaca.

Kata Kunci: Persona Deiksis, Pesan Persuasif, Buku Pengembangan Diri, Ingatkan Aku, Fitria NA

\section{PENDAHULUAN}

Perkembangan zaman membuat variasi tulisan dan buku menjadi lebih beragam. Di Indonesia sendiri beberapa waktu terakhir, toko buku diramaikan dengan berbagai buku pengembangan diri. Hal ini mengindikasikan bahwa masyarakat Indonesia sudah mulai membutuhkan konsumsi batiniah berupa nutrisi ketenangan pikiran dan jiwa, disamping paparan dan buku-buku tentang agama atau kepercayaan yang dianut.

Manusia selalu mencari cara untuk menyelesaikan masalah pribadi dengan memperluas keterampilan mental, fisik, sosial, dan profesional (Stine, 1997: 7). Hal itu dapat dijawab oleh buku pengembangan diri. Buku pengembangan diri adalah realisasi dari ideologi tertentu. Liang memperkenalkan adanya pengaruh ideologi dalam buku pengembangan diri. Ini menyiratkan bahwa cara penulis menulis buku pengembangan diri menunjukkan bahwa ideologi tertentu sedang dipromosikan, direalisasikan, dan dipertahankan (Liang, 2015: 40).

Buku Ingatkan Aku merupakan salah satu buku pengembangan diri atau self improvement yang memiliki kekuatan dalam pesan yang banyak mengingatkan manusia sebagai ciptaan-Nya. Banyak juga kata ganti persona yang muncul dalam buku ini dan perlu dianalisis keberadaannya merujuk pada apa dan siapa. Sehingga dapat diketahui pula pesan persuasif yang utuh dalam buku tersebut.

Untuk mengungkapkan gagasan penulis dalam buku pengembangan diri, diperlukan deiksis. Deiksis merupakan kata-kata terpilih yang memiliki referensi pada kata atau kalimat sebelumnya di dalam sebuah teks. Asal kata deiksis adalah dari bahasa Yunani, yakni deiktikos yang memiliki arti "hal penunjukkan secara langsung," (Nandar, 2013: 54). Hal ini berarti, kata deiksis tidak memiliki makna umum, melainkan selalu berpindah-pindah dan berganti-ganti rujukan bergantung pada referennya.

Deiksis merupakan kata rujukan dengan menyebutnya sebagai referensi (Nababan, 1987: 40). Referensi dalam hal ini merupakan kata atau frasa yang kembali merujuk pada kata, frasa, atau ungkapan yang digunakan dalam memberikan makna. Dengan begitu, kata atau frasa yang dikatakan deiksis adalah kata, frasa, atau ungkapan yang referensinya ada di dalam kalimat, baik sebelum maupun setelahnya.

Asal kata "persona" dalam deiksis persona merupakan adopsi dari bahasa Yunani yakni prosopon yang berarti dan bermakna "topeng", yang digunakan oleh pemain sandiwara untuk memberi watak dalam tokoh-tokoh drama. Rujukan yang dituju oleh kata ganti persona bergantung pada peserta tuturan atau tokoh dalam teks. Orang pertama sebagai pembicara atau penulis, orang kedua sebagai pendengar atau pembaca, sedangkan orang ketiga sebagai orang yang tidak hadir 
di tempat pembicaraan, tetapi menjadi bahan pembicaraan. Untuk lebih rinci, berikut dipaparkan jenis-jenis deiksis persona (orang) bahasa Indonesia yang (Yule, 2006: 15).

Buku pengembangan diri menyampaikan sebuah pesan mengajak atau disebut dengan pesan persuasif. Persuasi berasal dari kata persuation dalam bahasa Inggris yang berarti to persuade atau membujuk, merayu, meyakinkan, mempengaruhi, dan lain-lain (Widjaja, 2002: 67). Persuasi membawa sebuah pesan propaganda untuk membujuk, merayu, meyakinkan, mempengaruhi sesuatu.

Persuasi juga berarti suatu usaha untuk menciptakan kesesuaian dan kesepakatan melalui kepercayaan (Keraf, 2007: 118-119). Usaha-usaha yang diberikan adalah usaha yang tidak berbentuk paksaan. Hal tersebut agar individu atau kelompok lain yang menerima pesan persuasi diharapkan turut puas dan gembira.

Pesan persuasif adalah kekuatan yang diberikan penulis sebagai usaha untuk mengubah pikiran dan tindakan dengan memanipulasi motif-motif kearah tujuan yang telah ditetapkan (Jamiluddin, 2005: 1). Dalam hal itu, sebuah wacana dengan pesan persuasif diharapkan mampu mengubah pikiran dan tindakan sesuai yang disampaikan penulis.

Begitu erat keterkaitan buku pengembangan diri, deiksis, dan pesan persuasif. Proses penyampaian pesan memiliki tujuan dan maksud tertentu. Alasan tersebutlah yang mendasari hadirnya analisis terhadap buku pengembangan diri: Ingatkan Aku karya Fitria NA dengn fokus penggunaan deiksis persona dan pesan persuasif.

\section{METODE}

Penelitian ini termasuk jenis penelitian kualitatif. Metode penelitian deskriptif kualitatif, pengolahan kata atas temuan yang ditemukan dalam buku. Metode kualitatif yakni metode penelitian yang berdasarkan pada filsafat positivism. Biasanya digunakan untuk meneliti populasi atau sampel tertentu. Teknik pengabilan sampel simak-catat untuk menjawab fokus pembahasan yang telah ditetapkan (Sugiyono, 2015: 14).

Penelitian dilaksanakan terhadap penggunaan deiksis persona dan pesan persuasif dalam buku pengembangan diri: Ingatkan Aku karya Fitria NA. Penelitian ini dirancang untuk menganalisis deiksis persona dan pesan persuasif khususnya dalam kalimat-kalimat yang ada dalam buku dengan teknik pustaka, membaca, dan mencatat

Ada beberapa langkah analisis data yang dilakukan. Pertama, data berisi kutipan yang memiliki deiksis persona dikalsifikasikan berdasarkan jenisnya. Dari kata ganti tersebut dipaparkan alasan-alasan yang melatarbelakanginya sampai dengan makna.

Kedua, data yang sudah diklasifikasikan berdasarkan kata ganti itu diberikan analisis makna persuasinya. Dalam hal ini ditemukan makna-makna dibalik kata ganti yang ada dalam buku. 
Untuk mengecek keabsahan data, dilakukan proses triangulasi. Menurut Moleong (2011: 330), triangulasi adalah teknik pemeriksaan keabsahan data yang memanfaatkan sesuatu lain di luar data itu. Triangulasi bertujaun untuk keperluan pengecekan atau pembanding atas data yang telah dianalisis. Triangulasi juga dapat meningkatkan pemahaman peneliti terhadap apa yang telah ditemukan. Triangulasi pada penelitian ini dilaksanakan dengan cara diskusi bersama ahli dan sumber yang relevan. Tiga orang ahli yang dipilih yakni Fitria NA (Penulis Buku), Jaka Tirta Bayu, M.Pd. (Dosen STKIP Setia BudhiRangkasbitung), dan Ii Rusmiati, M.Pd. (Dosen STKIP Setia BudhiRangkasbitung).

Terakhir, peneliti menuliskan simpulan. Simpulan tersebut sebagai hasil korelasi deiksis persona dan pesan persuasif yang sudah ditemukan. Simpulan berdasarkan data dan kesimpulan berdasarkan seluruh simpulan data.

\section{HASIL DAN PEMBAHASAN}

\section{Hasil}

Buku Ingatkan Aku karya Fitria NA berisi 160 halaman yang terdiri dari kalimat, kutipan ayat Alquran, dan ilustrasi. Buku pengembangan diri ini dibuat untuk membangun motivasi pembaca dan mengingat kedudukan sebagai manusia di muka bumi.

Data yang berupa kalimat kutipan buku mulai diolah dengan memasukkannya ke dalam tabel pengategorian deiksis persona. Kemudian, kutipan tersebut diartikan pesan persuasifnya secara singkat. Untuk memperjelas analisis disajikan pula paparan analisis data yang ditemukan.

Ditemukan 67 data yang dianalisis berdasarkan deiksis persona yang digunakan dan pesan persuasif yang muncul. Bentuk deiksis persona dalam buku pengembangan diri: Ingatkan Aku karya Fitria NA didominasi oleh kata ganti orang kedua tunggal, yakni sebanyak 35 data, disusul kata ganti orang pertama (jamak: 21 dan tunggal: 9), dan data paling sedikit yakni orang ketiga tunggal yakni 2 data.

Dari data deiksis persona yang digunakan dalam buku, pesan-pesan persuasive muncul. Pesan tersebut didominasi oleh pesan-pesan religius. Artinya, pesan persuasif dalam buku pengembangan diri dapat berupa pesan-pesan keagamaan.

\section{Pembahasan}

Ingatkan Aku karya Fitria NA, merupakan salah satu buku pengembangan diri yang ada di Indonesia. Buku ini berisikan kata, ilustrasi, dan pesan yang mengingatkan kedudukan manusia di muka bumi.

Dominasi pengunaan kata ganti orang kedua tunggal menunjukkan bahwa buku pengembangan diri: Ingatkan Aku karya Fitria NA mengomunikasikan pesan dua arah.Yakni antara penulis dan pembaca. Hal ini sesuai dengan teori yang disampaikan bahwa kata ganti orang kedua adalah kategori rujukan yang 
menunjukkan kepada lawan tutur yang digunakan jika alamat atau penerima adalah individual Yule (2006: 15). Tujuan penggunaan tersebut adalah untuk menarik perhatian dan mengajak pembaca memahami, mengerti, dan melaksanakan anjuran-anjuran baik yang disampaikan penulis dalam buku pengembangan diri tersebut.

Komunikasi dua arah ini dilengkapi juga dengan kata ganti persona lainnya, seperti "kita" untuk menunjukkan kesamaan penulis dan pembaca, "aku" sebagai afirmasi diri, dan "-Nya" yang banyak menunjukkan kehadiran Tuhan. Penulis sangat piawai membangun diskusi kesadaran diri dalam buku yang ditulisnya tersebut.

Seluruh data yang ditemukan, mengandung pesan persuasif dan memenuhi lima komponen persuasi (Perloff, 2017: 21 s.d. 28).

Persuasion is a symbolic process. Kata-kata yang dipilih Fitria NA menyimbolkan pesan-pesan ajakan untuk selalu mengingat Tuhan.

Persuasion involves an attempt to influence. Usaha penulis agar pembaca sadar keberadaan dan posisi meraka di dunia diperkuat dengan adanya kutipankutipan Alquran.

People persuade themeselves. Di samping kutipan, banyak argumen yang akan membuat pembaca membuka logika dan perasaan manusia.

Persuation involves the transmission of a message. Penulis jarang menggunakan kata-kata memaksa pembaca atau menginterogasinya. Melainkan, banyak kata-kata ajakan yang penulis sendiri menjadi contoh secara langsung.

Persuasion requires free choice. Akibat tidak adanya paksaan, penulis membebaskan perilaku pembaca dengan rambu-rambu yang telah disampaikan yakni tentang keagamaan.

Dari lima komponen tersebut, tujuan penulis "mengingatkan" sangat tercapai. Mengingatkan diri manusia untuk sadar kedudukan dan fungsinya di dunia tanpa memaksa atu mendesak pembaca. Hal ini sesuai dengan tujuannya, buku pengembangan diri bertujuan untuk meningkatkan kualitas hidup dan dapat dijadikan terapeutik (Liang, 2015: 6).

Penggunaan deiksis persona dalam buku pengembangan diri berkaitan dengan penyampaian pesan persuasif. Keduanya memberi kesan saling menguatkan. Pesan yang dikirim secara personal (menggunakan kata ganti orang kedua yang dominan) dianggap efektif untuk memberikan nasihat dan pengingat. Penulisnya sangat mengharapkan pesan tersebut mampu dipahami, didalami, juga dilaksanakan secara personal oleh pembaca.

Hasil tersebut juga disepakati $100 \%$ oleh para triangulator dengan catatan 94\% sepakat dengan seluruh keterangan, sedangkan 6\% menambahkan saran penjelasan. Dengan begitu, artinya tiga narasumber (sebagai triangulator) menyetujui bahwa buku pengembangan diri Ingatkan Aku dapat memperkaya kajian deiksis dan analisis persuasif.

Hasil penelitian ini pun menunjukkan bahwa adanya implikasi pada teori deiksis persona dan pesan persuasif. Hal ini mampu menjawab pertanyaan bahwa deiksis persona dan pesan persuasif memiliki hubungan. Kajian ini dapat dijadikan pilihan bahan pembelajaran literasi oleh guru untuk bahan 
pengembangan diri siswa. Di samping itu, buku Ingatkan Aku mampu melengkapi pemahaman dan motivasi siswa dalam KI 1 yang berisi sikap religius siswa.

\section{SIMPULAN}

Berdasarkan hasil penelitian dan pembahasan dapat disimpulkan bahwa bentuk deiksis persona dalam buku pengembangan diri: Ingatkan Aku karya Fitria NA didominasi oleh kata ganti orang kedua tunggal, disusul kata ganti orang pertama (jamak dan tunggal), dan data paling sedikit yakni orang ketiga tunggal. Hal ini menunjukkan bahwa buku pengembangan diri: Ingatkan Aku karya Fitria NA menunjukkan komunikasi dua arah dalam tulisan antara penulis dan pembaca. Tujuannya, untuk menarik perhatian dan mengajak pembaca memahami, mengerti, dan melaksanakan anjuran-anjuran baik yang disampaikan penulis dalam buku pengembangan diri, pesan persuasif dalam buku pengembangan diri: Ingatkan Aku karya Fitria NA banyak memberikan pesan-pesan keagamaan. Sama seperti judul yang diberikan, buku ini mampu mengingatkan diri pembaca juga penulis untuk menjalankan hidup dengan mengingat Allah Swt., dan hubungan bentuk deiksis persona dan pesan persuasif dalam buku pengembangan diri: Ingatkan $A k u$ karya Fitria NA adalah kesan menguatkan. Dominasi deiksis persona yang muncul memperlihatkan bahwa pesan disampaikan dikirim secara personal. Sehingga, hal ini menguatkan pesan persuasif untuk dipahami, didalami, dan dilaksanakan pembaca.

Selain simpulan, berikut beberapa saran yang merujuk pada hasil penelitian yang telah dilakukan. Pertama, buku pengembangan diri: Ingatkan Aku karya Fitria NA dapat digunakan dalam pembelajaran bahasa dan sastra Indonesia SMP dan SMA sebagai bahan literasi. Kedua, buku pengembangan diri: Ingatkan Aku karya Fitria NA dapat dijadikan salah satu rujukan dalam pengkajian deiksis dan analisis pesan persuasif.

\section{DAFTAR RUJUKAN}

Jamiluddin. (2005). Tipologi pesan persuasif. Jakarta: Indeks.

Keraf, G. (2007). Argumentasi dan narasi. Jakarta: PT Gramedia Pustaka Utama.

Liang, K. D. (2015). Self-Improvement books-a genre analysis. (Tesis). Doctor of Philosophy in Applied Linguistics: Victoria University of Wellington.

Moleong, L. J. (2011). Metode penelitian kualitatif. Bandung: PT Remaja Rosdakarya.

Nababan, P. W. J. (1987). Ilmu pragmatik teori dan penerapannya. Jakarta: Departemen Pendidikan dan Kebudayaan.

Nandar, F. X. (2013). Pragmatik dan penelitian pragmatik. Yogyakarta: Graha Ilmu.

Perloff, R. M. (2017). The dynamic of persuation: Communication and attitudes in the 21st century. New York and London: Routledge. 
Stine, J. M. (1997). Writting succesful self-help and how to books. New York: John Wiley \& Sons, Inc.

Sugiyono. (2015). Metode penelitian pendidikan pendekatan kuantitatif, kualitatif, dan $R \& D$. Bandung: Alfabeta.

Widjaja, H. A. (2002). Komunikasi dan hubungan masyarakat. Jakarta: Bumi Aksara.

Yule, G. (2006). Pragmatik. Terjemahan Mustajab Rombe. Yogyakarta: Pustaka Pelajar. 